\title{
PENENTUAN KADAR LEMAK PADA FESES IKAN KERAPU MACAN (EPINEPHELUS FUSCOGUTTATUS) DENGAN METODE GRAVIMETRI MENGGUNAKAN PELARUT METANOL - KLOROFORM
}

\author{
I Made Gunamantha \\ Universitas Pendidikan Ganesha \\ Singaraja, Indonesia \\ e-mail: Gunamantha@gmail.com
}

\begin{abstract}
Abstrak
Penelitian ini bertujuan untuk (1) menentukan kadar lemak yang terdapat pada feses ikan kerapu macan, (2) mengetahui pengaruh variasi formulasi pakan terhadap kadar lemak pada feses ikan tersebut, dan (3) mengetahui pengaruh kondisi lingkungan, terutama suhu air terhadap kadar lemak pada feses ikan bersangkutan. Subjek penelitian ini adalah ikan kerapu macan (Epinephelus fuscoguttatus) yang diperoleh dari Balai Besar Riset Perikanan Budidaya Laut Gondol-Bali dan objek penelitiannya adalah kadar lemak pada feses ikan tersebut. Kadar lemak ditentukan dengan metode gravimetri menggunakan pelarut campuran metanol-kloroform (1:1). Hasil penelitian menunjukkan, bahwa (1) kadar lemak dalam feses ikan kerapu macan berkisar antara 3,51 - 13,36 \% pada pagi hari, dan 5,90 - 16,40\% pada siang hari, (2) variasi formulasi pakan yang diberikan sangat menentukan besar kecilnya kandungan kadar lemak dalam feses ikan tersebut, dan (3) perubahan kondisi lingkungan, yaitu peningkatan suhu air menyebabkan tingginya kandungan kadar lemak dalam feses ikan bersangkutan.
\end{abstract}

Kata kunci: Kadar Lemak, Gravimetri, Pelarut Metanol - Kloroform

\section{Pendahuluan}

Ikan kerapu macan (Epinephelus fuscoguttatus) merupakan salah satu komoditas perikanan yang mempunyai nilai ekonomis cukup tinggi, terutama di kawasan Asia. Harga kerapu macan dapat mencapai Rp 30.000,00 hingga Rp 50.000,00 per kilogram berat hidup (Slamet dan Tridjoko, 1997, dalam Sarida, 2005). Ikan kerapu disebut juga dengan nama goropa, sunu, atau kasai. Ikan kerapu memiliki spesies cukup banyak, diperkirakan lebih dari 46 spesies yang hidup di berbagi tipe habitat. Menurut Hemstra dan Randall (1993) dalam Triastini (2003), taksonomi ikan kerapu macan adalah sebagai berikut. a) Filum: Chordata, b) Subfilum: Vertebrata, c) Kelas: Osteichytes, d) Subkelas: Actinopterigi, e) Ordo: Percomorphi, f) Subordo: Percoidea, g) Famili: Serranidae, h) Genus: Ephinephelus, i) Spesies: Ephinephelus fuscoguttatus.

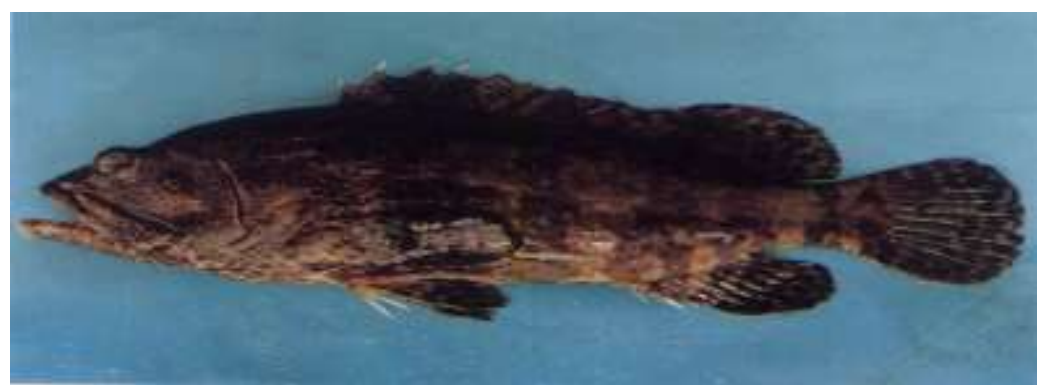

Gambar 1. Morfologi Ikan Kerapu Macan

Kerapu macan termasuk ikan karnivora yang sifat kanibalnya muncul apabila kekurangan pakan, terutama pada larva ikan kerapu macan. Ikan kerapu macan mempunyai kebiasaan makan pada pagi hari dan menjelang matahari terbenam. Pakan yang biasa diberikan dapat digolongkan menjadi dua jenis, yaitu pakan alami berupa zooplankton dan pakan buatan. 
Pakan buatan merupakan makanan ikan yang dibuat dari campuran bahan-bahan alami atau bahan olahan yang selanjutnya dilakukan proses pengolahan serta dibuat dalam bentuk tertentu, sehingga tercipta daya tarik yang merangsang ikan untuk memakannya dengan mudah dan lahap. Formulasi pakan buatan merupakan susunan energi dan nutrisi dalam jumlah yang seimbang sesuai dengan kebutuhan ikan untuk menunjang kelangsungan hidup dan pertumbuhannya. Formulasi pakan buatan yang disusun dari berbagai bahan baku memiliki kualitas yang lebih baik dibandingkan dengan pakan buatan yang tersusun hanya dari satu macam bahan, karena kekurangan nutrisi dari satu bahan baku akan dilengkapi oleh bahan baku lainnya (Abbas, 1995).

Agar dapat tumbuh dengan baik, benih kerapu macan membutuhkan pakan buatan dengan kandungan nutrisi yang tepat. Lemak merupakan salah satu nutrien penting dalam pakan buatan yang bermanfaat sebagai sumber tenaga, sumber asam lemak esensial, fosfolipid, sterol, dan pengantar vitamin. Dibandingkan dengan protein dan karbohidrat, lemak dapat menghasilkan tenaga yang lebih besar. Penggunaan lemak pada pakan berpengaruh terhadap rasa dan tekstur pakan yang dibuat, sehingga lemak juga mempunyai peran dalam proses metabolisme dan pertumbuhan ikan (Makatutu, 2001). Kekurangan lemak pada ikan kerapu macan dapat mengakibatkan timbulnya penyakit myopathy atau ceroidosis (Koesharyati et. al., 2001). Selain itu, kurangnya konsumsi lemak juga berpengaruh terhadap rendahnya tingkat pertumbuhan dan kelulushidupan ikan kerapu macan. Arifin (2002) menyatakan, bahwa ikan kerapu macan yang diberikan pakan buatan mengandung lemak mempunyai tingkat pertumbuhan dan kelulushidupan lebih tinggi dibandingkan pakan buatan tanpa lemak. Kandungan lemak dalam pakan buatan juga harus disesuaikan dengan kebutuhan ikan karena kadar lemak yang terlalu tinggi dapat menyebabkan terjadinya oksidasi lemak. Oksidasi lemak mengakibatkan permeabilitas membran sel menjdi terganggu, sehingga aktivitas metabolismenya berkurang (Lanrida, 2002).

Banyaknya lemak yang dikonsumsi oleh ikan bergantung pada komposisi bahan yang terdapat pada pakan tersebut dan juga kondisi lingkungannya. Untuk mengetahui pengaruh kedua faktor tersebut perlu dilakukan penelitian penentuan kadar lemak pada feses ikan kerapu macan dengan variasi formulasi pakan dan kondisi lingkungan yang berbeda. Penentuan kadar lemak tersebut dilakukan dengan metode gravimetri menggunakan pelarut metanol-kloroform (1:1). Pemilihan metode gravimetri untuk penentuan kadar lemak didasarkan pada ketelitian yang dihasilkan dan hematnya biaya yang harus dikeluarkan. Metode gravimetri bisa mencapai ketelitian $0,1 \%$ dengan kemampuan menentukan analit hingga konsentrasi $\pm 10^{-2}$ molar (Day dan Underwood, 1996). Penggunaan pelarut campuran metanol-kloroform karena keduanya mempunyai perbedaan kepolaran yang cukup besar. Selain itu kedua campuran pelarut tersebut memiliki titik didih yang rendah, sehingga mudah diuapkan pada suhu kamar untuk mendapatkan analit (lemak) dalam keadaan murni. Dengan demikian, lemak yang diperoleh tidak akan mengalami perubahan struktur molekul akibat pemanasan.

Hasil penelitian ini diharapkan dapat menjadi bahan informasi tambahan bagi pembaca, khususnya dalam menentukan variasi formulasi pakan dan kondisi lingkungan yang tepat bagi ikan kerapu macan, sehingga dapat menunjang pengembangan usaha budidaya ikan tersebut.

\section{Metode}

Penelitian ini dilaksanakan di Balai Besar Riset Perikanan Budidaya Laut Gondol-Bali selama 62 hari, dimulai dari tanggal 2 Mei hingga 2 Juli 2015.

Sebelum melakukan penelitian, terlebih dahulu dipersiapkan segala sesuatu yang dibutuhkan antara lain : bak, ikan kerapu macan, dan pakan ikan. Formulasi pakan ikan yang digunakan dibuat dalam 5 macam variasi. Masing-masing variasi formulasi diatur agar komposisi lemak dan protein dalam pakan sama, sedangkan komposisi lainnya dibuat berbedabeda (Tabel 1).

Tabel 1. Formulasi Pakan Ikan Kerapu Macan (Epinephelus fuscoguttatus)

\begin{tabular}{lccccc}
\hline \multirow{2}{*}{ Bahan } & \multicolumn{5}{c}{ Variasi Formulasi Pakan } \\
\cline { 2 - 6 } & $\mathbf{1}$ & $\mathbf{2}$ & $\mathbf{3}$ & $\mathbf{4}$ & $\mathbf{5}$ \\
\hline Tepung Ikan (gr) & 65,0 & 60,5 & 56,0 & 51,5 & 47,0 \\
Tepung Rebon (gr) & 10,0 & 10,0 & 10,0 & 10,0 & 10,0 \\
Tepung Ampas Kecap (gr) & 0,0 & 7,5 & 15,0 & 22,5 & 30,0 \\
Dekstrin/a-Starch (gr) & 13,1 & 11,0 & 8,8 & 6,7 & 4,5 \\
\hline
\end{tabular}




\begin{tabular}{lccccc}
\hline \multirow{2}{*}{ Bahan } & \multicolumn{6}{c}{ Variasi } & Formulasi Pakan \\
\cline { 2 - 6 } & $\mathbf{1}$ & $\mathbf{2}$ & $\mathbf{3}$ & $\mathbf{4}$ & $\mathbf{5}$ \\
\hline Minyak Ikan (gr) & 2,0 & 1,9 & 1,9 & 1,9 & 1,7 \\
Minyak Kedelai (gr) & 3,1 & 2,3 & 1,5 & 0,6 & 0,0 \\
Mineral Mix (gr) & 2,5 & 2,5 & 2,5 & 2,5 & 2,5 \\
Vitamin Mix (gr) & 1,3 & 1,3 & 1,3 & 1,3 & 1,3 \\
CMC (gr) & 2,0 & 2,0 & 2,0 & 2,0 & 2,0 \\
Metionin & - & - & - & - & - \\
$\mathrm{Cr}_{2} \mathrm{O}_{3}(\mathrm{gr})$ & 1,0 & 1,0 & 1,0 & 1,0 & 1,0 \\
Total (gr) & 100 & 100 & 100 & 100 & 100 \\
\hline & \multicolumn{5}{c}{ Komposisi Proximat } \\
\hline Protein (\%) & 46,8 & 46,8 & 46,8 & 46,8 & 46,8 \\
Lemak (\%) & 12,0 & 12,0 & 12,0 & 12,0 & 12,0 \\
Abu (\%) & 15,4 & 15,0 & 14,8 & 14,7 & 14,3 \\
Serat (\%) & 0,6 & 1,5 & 2,1 & 3,0 & 2,9 \\
Air (\%) & 5,32 & 5,1 & 4,5 & 4,0 & 3,7 \\
NFE (\%) & 19,97 & 19,63 & 19,81 & 19,50 & 20,26 \\
Energi (kkal/gr) & 78,77 & 78,43 & 78,61 & 78,30 & 79,06 \\
\hline
\end{tabular}

Pada awal penelitian hanya memberikan pakan pada ikan kerapu macan yang dilakukan dua kali sehari, yaitu pagi dan siang hari masing-masing sebanyak 2 gr selama 42 hari. Setelah 42 hari, pemberian pakan dihentikan, kemudian dilanjutkan dengan penentuan kadar lemak pada fesesnya. Pengambilan sampel feses ikan kerapu macan dilakukan secara acak dengan dua kali pengulangan.

Ditimbang sampel feses ikan kerapu macan yang diberi pakan dengan variasi formulasi 1 sebanyak 0,3 gram, kemudian dimasukkan ke dalam cawan pengaduk dan ditambah air sebanyak $0,6 \mathrm{ml}$ sambil diaduk secara manual hingga merata. Selanjutnya ke dalam cawan pengaduk ditambahkan pula $10 \mathrm{ml}$ metanol dan $20 \mathrm{ml}$ kloroform serta diaduk-aduk selama 5 menit. Setelah diaduk selama 5 menit, campuran sampel ditambah lagi dengan $10 \mathrm{ml}$ metanol dan diaduk selama 1 menit. Campuran sampel selanjutnya disaring dengan top filter paper dan ditampung dalam corong pemisah serta dicuci dengan pelarut metanol-kloroform dengan perbandingan 1:1. Hasil saringan ditambah larutan $\mathrm{NaCl} 0,9 \%$ sebanyak $7,5 \mathrm{ml}$ sambil dikocok, hingga homogen dan didiamkan selama satu malam sampai terbentuk dua lapisan. Lapisan bagian bawah (lemak dalam pelarut kloroform) ditampung dalam botol asah evaporator dan diuapkan dengan unit evaporator dalam ruang asam. Lemak yang diperoleh kemudian dipindahkan ke dalam botol lemak, dikeringkan dengan oven pengering pada suhu $40{ }^{\circ} \mathrm{C}$. Lemak yang sudah kering dimasukkan ke dalam desikator selama 30 menit kemudian ditimbang beratnya. Dengan cara yang sama ditentukan pula berat lemak yang diperoleh pada sampel feses ikan kerapu macan yang diberikan pakan dengan variasi formulasi 2, 3, 4, dan 5.

Dari hasil penelitian akan diperoleh data berupa berat sampel feses ikan kerapu macan yang diambil pada berbagai variasi formulasi pakan dan berat lemak yang diperoleh dari masing-masing sampel. Berdasarkan data tersebut, penentuan kadar lemak pada masingmasing sampel dapat dilakukan dengan memasukkan data yang diperoleh pada persamaan berikut.

$$
\text { Kadar lemak }(\%)=\frac{\text { Berat lemak yang diperoleh }}{\text { Berat sampel feses ikan yang diambil }} \times 100 \%
$$

Analisis selanjutnya dilakukan secara deskriptif mengenai pengaruh perbedaan variasi formulasi pakan dan kondisi lingkungan, terutama suhu air terhadap kandungan lemak dalam feses ikan kerapu macan.

\section{Hasil dan Pembahasan}

Berdasarkan hasil penelitian dan pengamatan yang dilakukan, diperoleh data kadar lemak pada feses ikan kerapu macan. Nilai kadar lemak ini diambil dari dua kali pengukuran, yaitu pada pagi hari dan siang hari dengan selang waktu 7 hari. Hasil pengukuran kadar lemak feses ikan kerapu macan dapat dilihat pada Tabel 2 untuk pagi hari, dan Tabel 3 untuk siang hari. 
Tabel 2. Nilai Kadar Lemak Feses Ikan Kerapu Macan (Epinephelus fuscoguttatus) Pagi Hari

\begin{tabular}{cccc}
\hline \multirow{2}{*}{ Variasi Formulasi Pakan } & \multicolumn{3}{c}{ Kadar Lemak (\%) } \\
\cline { 2 - 4 } & Sampel 1 & Sampel 2 & Rata-Rata \\
\hline 1 & 4,02 & 3,00 & 3,51 \\
2 & 4,30 & 4,28 & 4,29 \\
3 & 5,67 & 6,10 & 5,88 \\
4 & 11,92 & 11,91 & 11,91 \\
5 & 13,52 & 13,20 & 13,36 \\
\hline
\end{tabular}

Tabel 3. Nilai Kadar Lemak Feses Ikan Kerapu Macan (Epinephelus fuscoguttatus) Siang Hari

\begin{tabular}{cccc}
\hline \multirow{2}{*}{ Variasi Formulasi Pakan } & \multicolumn{3}{c}{ Kadar Lemak (\%) } \\
\cline { 2 - 4 } & Sampel 1 & Sampel 2 & Rata-Rata \\
\hline 1 & 6,12 & 5,68 & 5,90 \\
2 & 7,46 & 7,01 & 7,24 \\
3 & 11,08 & 11,50 & 11,29 \\
4 & 13,73 & 15,60 & 14,67 \\
5 & 16,10 & 16,76 & 16,40 \\
\hline
\end{tabular}

Dari Tabel 2, dapat dilihat bahwa kadar lemak pada feses ikan kerapu macan menunjukkan nilai yang berbeda untuk setiap variasi formulasi pakan. Nilai kadar lemak terendah terdapat pada feses ikan kerapu macan yang diberi pakan dengan variasi formulasi 1 , kemudian semakin meningkat pada varaiasi formulasi 2, 3, 4, dan pada variasi formulasi 5 nilai kadar lemak diperoleh dalam jumlah yang paling tinggi. Sebagaimana halnya dengan Tabel 2, Tabel 3 juga memperlihatkan hasil yang sama, namun kadar lemaknya lebih tinggi.

Perbedaan kadar lemak yang terkandung dalam feses ikan kerapu macan disebabkan oleh adanya perbedaan komposisi bahan pada masing-masing variasi formulasi pakan. Jika dilihat kembali komposisi pakan pada Tabel 1, variasi formulasi pakan 1-5 mengalami perubahan komposisi bahan baku, yaitu penambahan tepung ampas kecap, pengurangan tepung ikan, dan pengurangan kandungan minyak kedelai. Ketiga bahan baku ini merupakan sumber lemak bagi ikan kerapu macan. Pada setiap variasi formulasi pakan, penambahan jumlah tepung ampas kecap diiringi dengan pengurangan jumlah tepung ikan dan minyak kedelai, sehingga kadar lemak pada setiap variasi pakan tetap sama, yaitu sekitar $12 \%$. Meskipun kandungan kadar lemak pada setiap variasi formulasi pakan sama, namun pada kenyataanya kadar lemak pada feses ikan kerapu macan terdapat perbedaan. Hal ini dikarenakan tingkat pencernaan masing-masing bahan baku berbeda. Untuk mengetahui tingkat pencernaan suatu bahan dapat dilihat dari nilai ubahnya. Semakin tinggi nilai ubah suatu bahan baku, berarti semakin sulit bahan tersebut dicerna oleh ikan. Nilai ubah tepung ikan, minyak kedelai, dan tepung ampas kecap dicantumkan pada Tabel 4 (Mudjiman, 1984).

Tabel 4. Nilai Ubah Tepung Ikan, Minyak Kedelai, dan Tepung Ampas Kecap

\begin{tabular}{clc}
\hline No & \multicolumn{1}{c}{ Bahan } & Nilai Ubah \\
\hline 1 & Tepung ikan & $1,5-3$ \\
2 & Minyak kedelai & $3-5$ \\
3 & Tepung ampas kecap & 8 \\
\hline
\end{tabular}

Berdasarkan nilai ubah pada Tabel 4 di atas, dapat diketahui bahwa tepung ampas kecap lebih sulit dicerna oleh ikan dibandingkan tepung ikan maupun minyak kedelai. Akibatnya, kandungan lemak yang terdapat dalam tepung ampas kecap tidak sepenuhnya bias dicerna oleh ikan kerapu macan, melainkan dibuang dalam bentuk feses, sehingga kadar lemak pada feses menjadi meningkat.

Selain faktor variasi formulasi pakan, perbedaan kadar lemak pada feses juga dipengaruhi oleh waktu pemberian pakan. Feses ikan kerapu macan yang diberi pakan pada pagi hari (Tabel 2) mempunyai kadar lemak yang lebih rendah daripada siang hari (Tabel 3). Hal ini disebabkan oleh perbedaan lingkungan, terutama suhu air. Perubahan suhu air yang semakin meningkat pada siang hari, akan berpengaruh secara langsung terhadap nafsu makan ikan. Rata-rata kebutuhan pakan harian ikan kerapu pada siang hari meningkat dua kali lipat dibandingkan pada pagi hari (Abbas, 1996). Peningkatan kebutuhan pakan pada suhu tinggi 
tersebut disebabkan oleh meningkatnya agretivitas ikan untuk mendapatkan pakan. Pada suhu tinggi, ikan cenderung lebih agresif untuk mendapatkan pakan, sehingga frekuensi makannya menjadi lebih banyak. Namun karena kemampuan pencernaan ikan kerapu macan pada pagi maupun siang hari tetap sama, maka pakan yang dikonsumsi secara berlebihan akan terbuang menjadi feses. Akibatnya, kandungan lemak dalam feses menjadi lebih tinggi. Dengan demikian kadar lemak pada feses ikan kerapu macan saat siang hari lebih tinggi dibandingkan pagi hari.

\section{Simpulan dan Saran}

Berdasarkan rumusan masalah dan pembahasan di depan, simpulan dalam penelitian ini dapat dirumuskan sebagai berikut: kadar lemak dalam feses ikan kerapu macan berkisar antara 3,51 - 13,36 \% pada pagi hari, dan 5,90 - 16,40\% pada siang hari, variasi formulasi pakan yang diberikan sangat menentukan besar kecilnya kandungan kadar lemak dalam feses ikan kerapu macan, perubahan kondisi lingkungan, yaitu peningkatan suhu air, menyebabkan tingginya kandungan kadar lemak dalam feses ikan kerapu macan.

Selain kadar lemak, perlu juga ditentukan kandungan beberapa nutrien penting bagi ikan kerapu macan, seperti karbohidrat, protein, vitamin, dan mineral. Penentuan nutrien tersebut diperlukan untuk mengetahui pengaruhnya terhadap variasi formulasi pakan yang diberikan serta perbedaan kondisi lingkungan.

\section{Daftar Pustaka}

Abbas, S. D. 1995. Pakan Ikan Alami.Cetakan pertama. Yogyakarta: Kanisius.

Arifin. 2002. Pengaruh Kadar Asam Lemak N-3 HUFA yang Berbeda pada Pakan Buatan Terhadap Pertumbuhan dan Tingkat Kelulushidupan Juvenil Ikan Kerapu Macan (Epinephelus fuscoguttatus). Skripsi. Universitas Diponegoro.

Day, Jr. R. A. and Underwood, A. L. 1996. Analisis Kimia Kuantitatif. Terjemahan A. H. Pudjaatmaka. Quantitative Analysis. Cetakan ketiga. Jakarta: Erlangga.

Koesharyati, I. et. al. 2001. Penuntun Diagnosa Penyakit Ikan II. Balai Penelitian Laut Gondol.

Lanrida, M. 2002. Pengaruh Pemberian Pakan Buatan dengan Kandungan N-3 HUFA Berbeda Terhadap Pertumbuhan Juvenil Kerapu Macan (Epinephelus fuscoguttatus). Laporan Kerja Praktik Lapangan. Sekolah Tinggi Perikanan.

Makatutu, D. 2001. " Pengaruh Sumber Lemak Terhadap Pematangan Gonad dan Pemijahan Ikan Kerapu Lumpur (Epinephelus coiodes)". Makalah disampaikan dalam Lokakarya Teknologi Budidaya Laut dan Pengembangan Sea Farming di Indonesia, Puslitbang Eksplorasi Laut dan Perikanan, Jakarta 25 Januari 2001.

Mudjiman, A. 1984. Makanan Ikan. Jakarta: Swadaya.

Sarida, M. 2005. Pembenihan dan Pembesaran Kerapu Macan (Epinephelus fuscoguttatus) di Balai Besar Riset Perikanan Budidaya Laut Gondol - Bali. Laporan Praktik Kerja Lapang. Program Studi Teknologi dan Manejemen Akuakultur, Institut Teknologi Bogor.

Triastini, Ni G. K. 2003. Pengaruh Kandungan Vitamin C L-Ascorbyl-2-Phosphat Magnesium (APM) yang Berbeda pada Pakan Buatan Terhadap Pertumbuhan dan Kelangsungan Hidup Benih Ikan Kerapu Macan (Epinephelus fuscoguttatus). Skripsi. Jurusan Perikanan, Universitas Haluoleo Kendari. 